\section{Response to: 'Riociguat in systemic sclerosis: a potential for disease modification' by Jain and Dhir}

We thank Drs Jain and Dhir for their comments ${ }^{1}$ regarding our recent article in Annals of the Rheumatic Diseases entitled 'Riociguat in patients with early diffuse cutaneous systemic sclerosis (RISE-SSc): randomised, double-blind, placebo-controlled multicentre trial'. ${ }^{2}$ We agree that forced vital capacity (FVC) in millilitres, as in the Safety and Efficacy of Nintedanib in Systemic Sclerosis (SENSCIS) trial, ${ }^{3}$ may be informative, and that the effects of riociguat on swollen and tender joints are also of interest.

We present below (table 1) the results from RIociguat Safety and Efficacy in patients with diffuse cutaneous Systemic Sclerosis (RISE-SSc) for FVC in millilitres for the overall population and for patients with interstitial lung disease (ILD) at baseline according to medical history. The results are broadly consistent with those reported for $\mathrm{FVC} \% .{ }^{2}$ In view of the small sample sizes, a statistical analysis was not performed for the ILD subgroup. Data for total swollen joint scores and total tender joint scores are also shown. As the primary endpoint was not met, these data are purely descriptive and differences between the study arms cannot be considered statistically significant.

Data on tenosynovitis were not captured, and radiography was not routinely performed in the RISE-SSc study. Data on biomarkers including high-sensitivity C-reactive protein will be published as a separate paper.

Dinesh Khanna $\odot,{ }^{1}$ Oliver Distler ${ }^{2}$

\begin{tabular}{|c|c|c|}
\hline & Riociguat & Placebo \\
\hline \multicolumn{3}{|l|}{$\mathrm{FVC}$, mL, overall population } \\
\hline Baseline & $3068(954)(n=60)$ & $3294(909)(n=61)$ \\
\hline Week 52 & $2954(881)(n=55)$ & $3211(850)(n=51)$ \\
\hline Change from baseline at Week 52 & $-119(242)(n=55)$ & $-116(309)(n=51)$ \\
\hline \multicolumn{3}{|c|}{ FVC, mL, patients with ILD by medical history } \\
\hline Baseline & $2690(768)(n=12)$ & $3083(1221)(n=13)$ \\
\hline Week 52 & $2616(799)(n=11)$ & $2843(1168)(n=11)$ \\
\hline Change from baseline at Week 52 & $-95(113)(n=11)$ & $-244(347)(n=11)$ \\
\hline \multicolumn{3}{|c|}{ Total swollen joint score (overall population) } \\
\hline Baseline & $2.95(6.07)(n=60)$ & $1.07(2.55)(n=61)$ \\
\hline Week 52 & $2.29(5.11)(n=59)$ & $1.14(3.26)(n=59)$ \\
\hline \multicolumn{3}{|c|}{ Total tender joint score (overall population) } \\
\hline Baseline & $3.90(7.25)(n=60)$ & $2.10(4.78)(n=61)$ \\
\hline Week 52 & $3.73(7.09)(n=59)$ & $2.34(6.08)(n=59)$ \\
\hline
\end{tabular}

Values are mean (SD).

FVC, forced vital capacity; ILD, interstitial lung disease; RISE-SSc, Rlociguat Safety and

Efficacy in patients with diffuse cutaneous Systemic Sclerosis; SD, standard deviation.
${ }^{1}$ Division of Rheumatology, University of Michigan, Ann Arbor, Michigan, USA ${ }^{2}$ Department of Rheumatology, University Hospital Zurich, Zurich, Switzerland

Correspondence to Dinesh Khanna, Division of Rheumatology, University of Michigan, Ann Arbor, MI 48109, USA; khannad@med.umich.edu

\section{Handling editor Josef S Smolen}

Contributors DK and OD jointly drafted and reviewed the manuscript and approved the final version for submission.

Funding Funding for this research was provided jointly by Bayer $A G$ and Merck Sharp \& Dohme Corp., a subsidiary of Merck \& Co., Inc., Kenilworth NJ, USA. Medical writing services provided by Richard Murphy PhD, of Adelphi Communications Ltd, Macclesfield, UK and were funded by Bayer AG, Berlin, Germany in accordance with Good Publication Practice (GPP3) guidelines.

Competing interests DK reports grant support from $\mathrm{NIH}$, Immune Tolerance Network, Bayer AG, Bristol-Myers Squibb, Horizon, Pfizer; consultancy with Acceleron, Actelion, AbbVie, Amgen, Bayer AG, Boehringer Ingelheim, CSL Behring, Corbus, Galapagos, Genentech/Roche, GlaxoSmithKline, Horizon, Merck, Mitsubishi Tanabe Pharma, Sanofi-Aventis, and United Therapeutics; and ownership of stocks in Eicos Sciences, Inc. OD reports consultancy relationship and/or has received research funding from AbbVie, Actelion, Acceleron Pharma, Amgen, AnaMar, Baecon Discovery, Blade Therapeutics, Bayer AG, Boehringer Ingelheim, Catenion, Competitive Corpus, Drug Development International Ltd, CSL Behring, ChemomAb, Ergonex, Galapagos NV, Glenmark Pharmaceuticals, GlaxoSmithKline, Horizon (Curzion) Pharmaceuticals, Inventiva, Italfarmaco, iQone, iQvia, Kymera Therapeutics, Lilly, medac, Medscape, Mitsubishi Tanabe Pharma, MSD, Novartis, Pfizer, Roche, Sanofi, Target Bio Science and UCB in the area of potential treatments of scleroderma and its complications. In addition, he has a patent mir-29 for the treatment of systemic sclerosis issued (US8247389, EP2331143)

Patient and public involvement Patients and/or the public were not involved in the design, or conduct, or reporting or dissemination plans of this research.

Patient consent for publication Not required.

Provenance and peer review Commissioned; internally peer reviewed.

(c) Author(s) (or their employer(s)) 2020. No commercial re-use. See rights and permissions. Published by BMJ.

\section{Check for updates}

To cite Khanna D, Distler O. Ann Rheum Dis Epub ahead of print: [please include Day Month Year]. doi:10.1136/annrheumdis-2020-218194

Received 16 June 2020

Accepted 16 June 2020

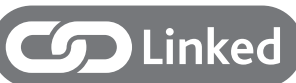

- http://dx.doi.org/10.1136/annrheumdis-2020-218180

Ann Rheum Dis 2020;0:1. doi:10.1136/annrheumdis-2020-218194

\section{ORCID iDs}

Dinesh Khanna http://orcid.org/0000-0003-1412-4453

Oliver Distler http://orcid.org/0000-0002-0546-8310

\section{REFERENCES}

1 Jain S, Dhir V. Riociguat in systemic sclerosis: a potential for disease modification. Ann Rheum Dis 2020. doi: 10.1136/annrheumdis-2020-218180.

2 Khanna D, Allanore Y, Denton CP, et al. Riociguat in patients with early diffuse cutaneous systemic sclerosis (RISE-SSc): randomised, double-blind, placebo-controlled multicentre trial. Ann Rheum Dis 2020;79:618-25.

3 Distler O, Highland KB, Gahlemann M, et al. Nintedanib for systemic sclerosisassociated interstitial lung disease. N Engl J Med 2019;380:2518-28. 